Fábio Markus Nunes Miranda

\title{
Volume rendering of unstructured hexahedral meshes
}

Dissertation presented to the Postgraduate Program in Informatics, of the Departamento de Informática, PUC-Rio as partial fulfillment of the requirements for the degree of Mestre em Informática.

Advisor: Prof. Waldemar Celes 
Fábio Markus Nunes Miranda

\title{
Volume rendering of unstructured hexahedral meshes
}

Dissertation presented to the Postgraduate Program in Informatics, of the Departamento de Informática do Centro Técnico Científico da PUC-Rio, as partial fulfillment of the requirements for the degree of Mestre.

\author{
Prof. Waldemar Celes \\ Advisor \\ Departamento de Informática - PUC-Rio \\ Prof. Marcelo Gattass \\ Department of Computer Science - PUC-Rio
}

Prof. Thomas Lewiner

Department of Mathematic - PUC-Rio

Prof. Luiz Henrique de Figueiredo

Instituto Nacional de Matemática Pura e Aplicada (IMPA)

Prof. José Eugenio Leal Coordinator of the Centro Técnico Científico - PUC-Rio 
All rights reserved.

\section{Fábio Markus Nunes Miranda}

Fabio Markus Miranda graduated from Universidade Federal de Minas Gerais (UFMG) with a B.Sc. in Computer Science in 2009. While at UFMG, he received scholarships from CNPq in the bioinformatics area and later Finep. In 2009, he started the graduate program in Computer Science at PUC-Rio. In 2010 he joined the Computer Graphics Technology Group (Tecgraf), contributing to the group's work for Petrobras.

Bibliographic data

Miranda, Fábio Markus

Volume rendering of unstructured hexahedral meshes / Fábio Markus Nunes Miranda ; advisor: Waldemar Celes. 2011.

$47 \mathrm{f}$ : : il. ; $30 \mathrm{~cm}$

Dissertação (Mestrado em Informática)-Pontifícia Universidade Católica do Rio de Janeiro, Rio de Janeiro, 2011.

Inclui bibliografia

1. Informática - Dissertação. 2. Renderização volumétrica. 3. Malha de hexaedros. 4. Malha não estruturada. 5. Integral do raio. I. Celes, Waldemar. II. Pontifícia Universidade Católica do Rio de Janeiro. Departamento de Informática. III. Título. 


\section{Acknowledgments}

To my family, my adviser, my friends and collegues.

To CAPES and Tecgraf for the financial support. 


\section{Resumo}

Miranda, Fábio Markus; Celes, Waldemar. Renderização volumétrica de malha não estruturada de hexaedros. Rio de Janeiro, 2011. 47p. Dissertação de Mestrado - Departamento de Informática, Pontifícia Universidade Católica do Rio de Janeiro.

Importantes aplicações de engenharia usam malhas não estruturadas de hexaedros para simulações numéricas. Células hexaédricas, comparadas com tetraedros, tendem a ser mais numericamente estáveis e requerem um menor refinamento da malha. Entretando, visualização volumétrica de malhas não estruturadas é um desafio devido a variação trilinear do campo escalar dentro da célula. A solução convencional consiste em subdividir cada hexaedro em cinco ou seis tetraedros, aproximando uma variação trilinear por uma inadequada série de funções lineares. Isso resulta em imagens inadequadas e aumenta o consumo de memória. Nesta tese, apresentamos um algoritmo preciso de visualização volumétrica utilizando ray-casting para malhas não estruturadas de hexaedros. Para capturar a variação trilinear ao longo do raio, nós propomos usar uma integração de quadratura. Nós também propomos uma alternativa rápida que melhor aproxima a variação trilinear, considerando os pontos de mínimo e máximo da função escalar ao longo do raio. Uma série de experimentos computacionais demonstram que nossa proposta produz resultados exatos, com um menor gasto de memória. Todo algoritmo é implementado em placas gráficas, garantindo uma performance competitiva.

\section{Palavras-chave}

Renderização volumétrica; Malha de hexaedros; Malha não estruturada; Integral do raio; 


\section{Abstract}

Miranda, Fábio Markus; Waldemar Celes (Advisor). Volume rendering of unstructured hexahedral meshes. Rio de Janeiro, 2011. 47p. MSc Dissertation - Departamento de Informática, Pontifícia Universidade Católica do Rio de Janeiro.

Important engineering applications use unstructured hexahedral meshes for numerical simulations. Hexahedral cells, when compared to tetrahedral ones, tend to be more numerically stable and to require less mesh refinement. However, volume visualization of unstructured hexahedral meshes is challenging due to the trilinear variation of scalar fields inside the cells. The conventional solution consists in subdividing each hexahedral cell into five or six tetrahedra, approximating a trilinear variation by an inadequate piecewise linear function. This results in inaccurate images and increases the memory consumption. In this thesis, we present an accurate ray-casting volume rendering algorithm for unstructured hexahedral meshes. In order to capture the trilinear variation along the ray, we propose the use of quadrature integration. We also propose a fast approach that better approximates the trilinear variation to a series of linear ones, considering the points of minimum and maximum of the scalar function along the ray. A set of computational experiments demonstrates that our proposal produces accurate results, with reduced memory footprint. The entire algorithm is implemented on graphics cards, ensuring competitive performance.

\section{Keywords}

Volume Rendering; Hexahedral Mesh; Unstructured Mesh; Ray Integral; 


\section{Contents}

1 Introduction $\quad 11$

2 Related Work $\quad 15$

$\begin{array}{lll}2.1 & \text { Ray integration } & 15\end{array}$

2.2 Hexahedral meshes 16

3 Accurate Volume Rendering of Hexahedral Meshes 18

$\begin{array}{lll}3.1 & \text { Ray integration } & 18\end{array}$

3.2 Integration intervals 20

3.3 Data structure 21

$\begin{array}{ll}3.4 & \text { Ray traversal } \\ 3.5 & 22\end{array}$

$\begin{array}{ll}3.5 & \text { Isosurfaces }\end{array}$

3.6 Algorithm Overview 23

4 Fast Volume Rendering of Hexahedral Meshes 25

$\begin{array}{lll}4.1 & \text { Ray integration } & 25\end{array}$

$\begin{array}{ll}4.2 & \text { Integration intervals } \\ \end{array}$

$\begin{array}{llr}5 & \text { Results } & \mathbf{2 7}\end{array}$

$\begin{array}{ll}5.1 & \text { Rendering quality } \\ 5.2 & \text { Timeresuls }\end{array}$

5.2 Time results 34

$\begin{array}{lll}6 & \text { Conclusion } & 36\end{array}$

$\begin{array}{lll}7 & \text { Bibliography } & 37\end{array}$

$\begin{array}{ll}\text { A Control point texture } & 39\end{array}$

B 2D Pre-integration table texture $\quad 41$

C Unstructured Tetrahedral Meshes $\quad 42$

C.1 Ray integration 42

C.2 Data structure 42

C.3 Traversal 43

C.4 Algorithm Overview 43

D Regular data $\quad 44$

D.1 3D Pre-integration table texture 45

$\begin{array}{lll}\text { D.2 Data structure } & 45\end{array}$

D.3 Algorithm Overview 46 


\section{List of Figures}

1.1 Meshes types. 11

1.2 Volume rendering examples. ${ }^{1} \quad 12$

$\begin{array}{ll}1.3 \text { An example of a transfer function } & 12\end{array}$

1.4 Example of four transfer functions on a MRI dataset. 13

3.1 Example of scalar field variation inside a hexahedral cell: (a) Maximum and minimum values of a trilinear function along the ray inside an hexahedron; (b) Transfer function represented by a piecewise linear variation. $\quad 21$

3.2 Isosurface rendering of the Atom9 dataset. 23

4.1 Piecewise linear functions, considering the maximum and minimum values of a trilinear scalar function. 25

5.1 Bucky dataset isosurfaces. 28

5.2 Rendering on a synthetic model composed by on hexahedron. 29

5.3 Images of the Bucky model. 30

5.4 Images of the Bluntfin model. 31

5.5 Achieved images using a synthetic model. 33

5.6 Volume rendering of the Bluntfin Dataset. 35

D.1 Structured ray-casting steps. 44

D.2 Structured ray-casting, using the same number of steps. 45 


\section{List of Tables}

3.1 Data structure for one hexahedral cell. 21

3.2 Ray-casting Algorithm 24

5.1 Rendering times and memory footprint of the subdivision scheme and our proposal.

A.1 Control point texture algorithm 40

C.1 Data structure for one tetrahedral cell. 42

C.2 Ray-casting Algorithm 43

D.1 3D pre-integration table algorithm 46

D.2 Structured data post-classification ray-casting algorithm 46

D.3 Structured data pre-integration ray-casting algorithm 47 
I seldom end up where I wanted to go, but almost always end up where I need to be.

Douglas Adams, The Hitchhiker's Guide to the Galaxy. 